\title{
PENDAMPINGAN BIMBINGAN BELAJAR MATEMATIKA BERBANTUAN BUKU SAKU MELALUI MEDIA PERMAINAN MONOPOLI UNTUK MENANAMKAN MINAT BELAJARSISWA DALAM BERHITUNG DI SDN 020 RW 02 KELURAHAN SEI LANGKAI
}

\section{MATH LEARNING TUTORIAL ASSISTANCE BY USING MONOPOLI POCKET AS A MEDIA TO PROMOTE STUDENTS' LEARNING INTEREST AT SDN 020 RW 02 KELURAHAN SUNGAI LANGKAI}

\author{
Yesi Gusmania $^{1}$,Nina Agustyaningrum ${ }^{2}$ \\ 1,2 (Prodi Pendidikan Matematika, Fakultas Keguruan dan Ilmu Pendidikan, \\ Universitas Riau Kepulauan, Indonesia) \\ 'yesigusmania18@gmail.com, ${ }^{2}$ agustyaningrum@gmail.com
}

\begin{abstract}
Abstrak
Pengabdian masyarakat ini bertujuan sebagai salah satu kegiatan pengembangan diri bagi siswa didik dengan memberikan pengalaman belajar yang bermakna dan bervariasi. Berdasarkan survey studi lapangan dengan masyarakat RW 02 kelurahan sei langkaibahawa mengalami kesulitan disaat menyelesaikan tugas yang diberikan disekolah yang berhubungan dengan masalah berhitung. Selain itu, penjelasan secara langsung oleh guru yang didominasi dengan pemberian ceramah.Hal ini disebabkan karena pembelajaran yang dilaksanakan selama ini di SDN 20 sangat jarang menggunakan metode-metode yang inovatif dan media yang digunakan belum maksimal, sehingga kurangnya minat belajar siswa dalam operasi berhitung. Salah satu cara yang digunakan pendidik untuk meningkatkan minatbelajar siswa, adalah dengan memberikan variasi media dengan menggunakan permainan monopoli. Permaianan monopoli dapat dilakukan secara berkelompok melalui pelaksanaan berupa prosedur permaian, stimulasi dan permainan monopolinya. Hasilnya menunjukkan bahwa: (1)siswa sangat antusias, ketika mereka disuruh untuk mengerjakan soal yang diberikandan direspon dengan baik., (2) Pelaksanaan program pengabdian pada masyarakat ini sangat bermanfaat bagi siswa SDN 020, sehingga dapat diterapkan media berbantuan buku saku dengan metode permainan (monopoli) untuk menanamkan minat belajar siswa dalam menghitung.
\end{abstract}

Kata Kunci : Buku saku, Permainan monopoli, minat belajar siswa

\section{Abstract}

This community service aims to be a self development activity for student by providing meaningful and varied learning experience. Based on a field study survey with the community of $R W 02$ Sei Langkai village that experienced difficulties when completing the assignment given in in school related to country problems. In addition, direct explanations by teacher dominated by giving lectures. This is because learning that has been carried out so far in SDN 20 very rarely uses innovative methods uses innovative method and the media used has not been maximized, resulting in a lack of interest in student learning in counting operations. One of the method used by educator to increase student learning interest is to provide media variations using monopoly games. Monopoly games can be done in groups hrough the implementation of game procedures, stimulation and monopoly play.The results show that : (1). Students were very enthuasiastic, when they were told to work on the questions given and responded well.(2). The implementation of this community service program is very beneficial for students SDN 20, so that it can be applied to pocket book assisted media using the game method(monopoly) to instill the concept of how to calculate easily.

Keywords: Pocket book, Monopoly Game, Student Learning Interest. 


\section{PENDAHULUAN}

Pendidikan adalah wujud kebudayaan manusia yang dinamis dan terus berkembang. Perkembangan dalam dunia pendidikan terus berkembang sejalan dengan perkembangan kebudayaan manusia. Kegiatan pengembangan juga dilakukan melalui sejumlah mata pelajaran yang dapat memberikan pengalaman belajar bagi siswa (BSNP, 2006). Di negara-negara yang sedang berkembang, pertumbuhan penduduk tidak terkendali dan ada kecenderungan bertambah di wilayah perkotaan. Wilayah Kelurahan Sei Langkai yang merupakan salah satu kawasan padat penduduk dengan jumlah penduduk yang terdiri dari 43.224 jiwa. Dengan jumlah KK 381,diantaranya RT 01 berjumlah 93 KK, RT 02 berjumlah 65 KK, RT 03 berjumlah 115 KK, dan RT 04 berjumlah 108 KK. Terkait dengan kepadatan penduduknya, Kelurahan sei langkai salah satu wilayah yang memiliki SDN 020 yang terdiri dari kelas 1-6. Anak-anak di RW 02 kelurahan sei langkai menikmati pendidikan seperti yang seharusnya mulai dari jenjang taman kanak-kanak sampai perguruan tinggi. Berdasarkan hasil wawancara dengan beberapa siswa di RW 02 diperoleh Informasi yang cukup menarik bahwa untuk pembelajaran matematika, khususnya sering mengalami kesulitan disaat menyelesaikan tugas yang diberikan oleh guru di sekolah yang berhubungan dengan masalah berhitung, banyak siswa yang belum bisa berhitung terutama dalam soal cerita serta masih minimnya media pembelajaran yang digunakan di SDN 20 dan kurangnya minat belajar.

Hal ini disebabkan bahwa pembelajaran yang dilaksanakan selama ini di SDN 20 sangat jarang menggunakan metode-metode yang inovatif dan kurangnya memanfaatkan kemajuan teknologi seperti minimnya penggunaan media pembelajaran. Siswa belajar matematika lebih banyak melalui penjelasan secara langsung oleh guru yang didominasi dengan pemberian ceramah. Sebagai akibatnya siswa belajar matematika dengan cara-cara yang kurang bermakna. Sehingga belajar menjadi momok tersendiri bagi mereka karena cenderung menghabiskan waktu luang untuk bermain (Artantri, 2005). Adapun tujuan dalam pengabdian yang dilakukan bersama dengan anak SD N 020 adalah sebagai salah satu kegiatan pengembangan diri bagi siswa didik dengan memberikan pengalaman belajar yang bermakna dan bervariasi.

Sangat diperlukan variasi media dan metode dalam proses pembelajaran,sehinggadapat meningkatkan hasil belajar siswa. Keberhasilan proses 
pembelajaran sangat ditentukan oleh metode pengajaran yang baik, media pembelajaran yang mendukung serta suasana proses belajar yang kondusif. Keterampilan pendidik dalam menumbuhkan motivasi siswa juga merupakan salah satu faktor yang mempengaruhi keberhasilan tersebut (Husna, 2017). Salah satu media pembelajaran yang digunakan adalah membuat media sendiri yaitu berbentuk buku saku. Didalam media tersebut dibuat ringkasan materi, gambar yang menarik untuk mengairah minat belajar siswa. Hal ini juga sejalan dengan pendapat Soefudin (dalam Suprapto, 2013) media pembelajaran adalah berbagai macam alat yang dapat digunakan sebagai sumber informasi dan komunikasi dan merangsang keterlibatan siswa dalam proses belajar.

Pemilihan media yang akan digunakan disesuaikan dengan materi dan jenis metode pembelajaran yang digunakan. Menurut Ismawati (2012), dalam pemilihan media didasarkan pada hal-hal berikut: (1) mengetahui karakteristik media, (2) tujuan yang akan dicapai, (3) metode yang akan digunakan, (4 materi yang akan disampaikan, (5) kondisi persta didik, (6) kondisi lingkungan, (7) kemampuan dan kreativitas guru. Sedangkan menurut pendapat gagne (dalam Sartikaningrum 2013) bahwa media pembelajaran meliputi alat yang secara fisik digunakan untuk menyampaikan isi materi pengajaran, yang terdiri dari buku, tape, recorder, kaset, video kamera, video recorder, film slade, foto gambar, grafik dan computer. Salah satu media pembelajaran yang diguanakan adalah dengan mebuat media sendiri yaitu berbentuk buku saku. Dari kedua pendapat tersebut disimpulkan bahwa media tersebut dibuat ringkasan materi, gambar yang menarik untuk mengairah minat belajar siswa.

Adapun proses pembelajaran dalam penyampaian media yang digunakan melalui metode permainan monopoli.Permainan (games) setiap kontes antara pemain yang berinteraksi satu sama lain dengan mengikuti aturan-aturan tertentu dalam mencapai tujuan tertentu pula. Setiap permainan harus mempunyai empat komponen utama yaitu : (1) Adanya pemain (pemain-pemain), (2) Adanya lingkungan dimana para pemain berinteraksi, (3) Adanya aturan-aturan main, (4) Adanya tujuan tertentu yang ingin di capai (Sardiman, 2011).

Menurut (Sardiman, 2011) di dalam permainan monopoli memiliki beberapa kelebihan, diantaranya:

1. Permainan adalah sesuatu yang menyenangkan untuk dilakukan sesuatu yang menghibur 
2. Permainan memungkinkan adanya partisipasi aktif dari siswa untuk belajar

3. Permainan dapat memberikan umpan balik langsung

4. Permainan memungkinkan penerapan konsep-konsep ataupun peran-peran ke dalam situasi dan peranan yang sebenanrnya di masyarakat

5. Permainan bersifat luwes

\section{METODOLOGI}

\section{Material}

Proses pembelajaran dapat dilakukan di rumah dengan melibatkan orang-orang di sekitar anak tersebut seperti orang tua. Orang tua dapat mengambil peran aktif untuk mengajarkankepada putra putrinya. Tentu saja materi pembelajaran itu perlu dikemas sedemikian rupa sehingga anak tertarik untuk mempelajarinya. Tanpa disadarinya ketika sedang bermain, anak tersebut telah masuk dalam proses pembelajaran.Hal ini sesuai dengan pendapat Seto (2010) bahwabermain dapat memberikan kesempatan pada individu untuk berpikir dan bertindak imajinatif serta penuh daya khayal yang erat hubungannya dengan perkembangan kreativitas anak.

Pertama kali yang harus diperhatikan adalah suasana ruangan dimana anak melakukan aktivitas pembelajaran.Kita harus dapat menciptakan suasana yang relax pada saat proses pembelajaran berlangsung. Selain itu materi harus dikemas semenarik mungkin karena anak-anak cenderung mudah bosan terhadap aktivitas yang monoton. Berikut ini adalah kegiatan pembelajaran matematika yang dapat dilakukan di rumah:

a) Kita juga dapat memutar film tentang pembelajaran sebagai media untuk menarik minat anakdan dapat mengasah kemampuan mereka untuk memahami pelajaran matematika.

b) Internet juga dapat digunakan sebagai sumber pembelajaran. Banyak program online yang dapat digunakan sebagai materi pembelajaran sepertigame, dan aktivitas yang lain.

\section{Metode}

Dalam program bimbingan belajar ini, digunakan beberapa metode, antara lain :

1. Metode Tanya Jawab, yaitu digunakan untuk merespon sejauh mana tingkat pemahaman siswa terhadap yang telah disampaikan oleh Tim Pelaksana Pengabdian Kepada Masyarakat Universitas Riau Kepulauan.

2. Metode Diskusi, yaitu pemateri dan peserta melakukan diskusi bersama dengan anak dan 
pembentuk kelompoksiswa dalam Menumbuhkembangkan Potensi siswa dalam belajar.

3. Metode permainan, yaitu digunakan untuk melihat minat belajar siswa dalam belajar matematika.

\section{PEMBAHASAN}

Kegiatan pengabdian masyarakat ini dilaksanakan dengan beberapa metode seperti metode tanya jawab, diskusi, dan metode permainan sambil bermain.Pelaksanaan dilaksanakan dua kali pertemuan yaitu sabtu tanggal, 28 juli dan 04 agustus 2018 Pukul 09.00- 11.00 wib dan tanggal 11 agustus 2018 pukul 08.15-10.50 wib bertempat di SD Negeri 020 di RW 02 kelurahan Sei Langkai dengan banyak peserta 25 orang. Materi atau topik pembelajaran disesuaikan dengan kebutuhan peserta yang ada di tempat pengabdian dengan materinya" Operasi hitung, operasi hitung dalam soal cerita serta operasi hitung campuran bilangan bulat".

Hasil-hasil yang dicapai dalam pelaksanaan program bimbel belajar merupakan pelajaran tambahan di luar jam sekolah. Pelaksanaan program bimbel matematika dilaksanakan di SDN 020 RW 02 kelurahan Sei Langkai. Program ini bersifat runtinitas dalam kehidupan sehari-hari mereka. Pelaksanaan bimbingan belajar pada pembelajaran matematika ini mendapat sambutan dan respon yang baik dari masyarakat kelurahan Sei Langkai RW 02, hal ini terbukti dari banyak peserta didik yang ikut bimbel sebanyak 25 orang. Kegiatan bimbingan belajar matematika ini berupa pemberian materi, yang ikuti dengan permainan monopoli seperti permainan ular tangga untuk menghitung bilangan bulat dengan cepat agar peserta didik tidak bosan \& tidak jenuh dalam berhitung.

Adapun teknis pelaksanaan bimbingan belajar matematika anak-anak SDN 020 RW 02 kelurahan Sei Langkaisebagai berikut:

\section{Tahap Awal}

Pada tahap awal ini, menyiapkan media pembelajaran seperti buku saku yang berisi materi-materi penting yaitu operasi hitung, operasi hitung dalam soal cerita serta operasi hitung campuran bilangan bulat dan materi lainnya untuk pegangan mereka belajar di rumah, dan peserta menyiapkan permainan monopoli dari ular tangga. Sebelum pembelajaran dimulai siswa diberikan pengenalan materi yang akan diajarkan, kemudian siswa ditanya satu persatu tentang hal-hal yang berhubungan dengan materi yang diajarkan.

2. Tahap Pelaksanaan 
Pada tahap pelaksanaan cara pemberian materi tidak sama setiap kali pelaksanaan bimbingan belajar matematika, karena cara pemberian materi menyesuaikan dengan materi yang diajarkan. Adapun proses pembelajaran yang dilakukan dengan permainan monopoli sebagai berikut:

a) Memberikan stimulasi kepada anak-anak SDN 020 dalam permainan monopoli

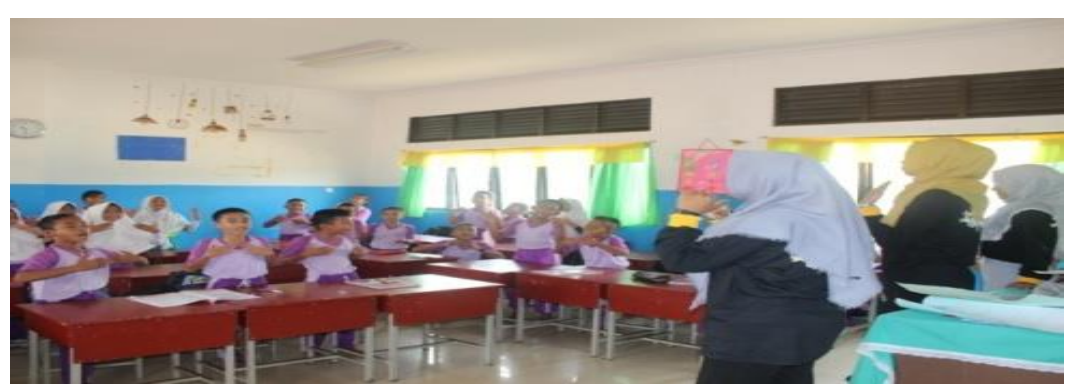

Figur 1. Foto Pemberian stimulasi melalui permainan monopoli

b) Menjelaskan aturan bermain dengan permainan monopoli dan membagi kelompok untuk mendiskusikan materi serta membagi buku saku tiap kelompoknya.

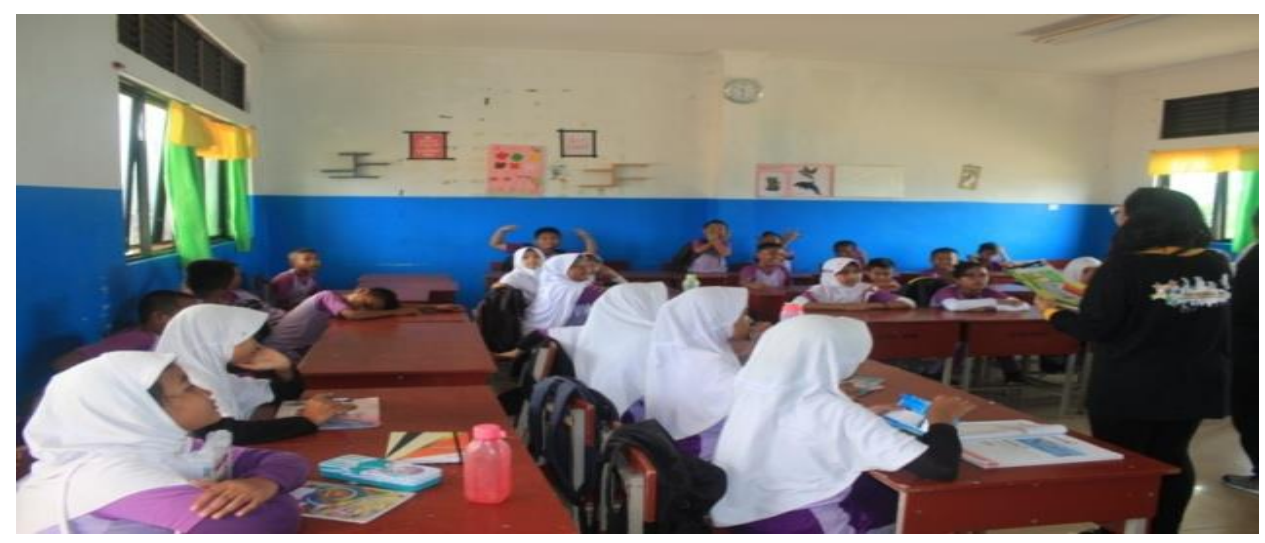

Figur 2. Foto Proses pembagian kelompok dalam pembelajaran dengan permainan monopoli

Ketika tutornya saat menjelaskan aturan permainan, mereka terlihat antusias dan bersemangat dalam belajar dengan penuh perhatian mendengarnya. Setelah itu, tutornya membagi buku saku tiap kelompok untuk masing-masing beserta ular tangganya (permainan monopoli). Diawal pembelajaran, mereka belum mengetahui cara menghitung bilangan bulat dengan cepat apalagi angka bilangan bulatnya paling besar seperti - $120+$ 30, mereka belum bisa untuk menjawabnya. Kadang mereka malu dan takut-takut untuk 
menjawab. Ketika mengajarkan materi operasi bilangan bulat tutornya memberikan contoh soal yang ada di buku saku dengan cara menggunakan monopoli tersebut, Setelah itu, mereka diminta untuk mendiskusikan dengan kelompoknya tentang materi yang ada di buku sakunya sambil bermain dengan monopoli (ular tangga). Karena di dalam buku saku ada beberapa soal latihan untuk mereka jawab. Dengan menggunakan permainan monopoli, mereka dapat menjawab latihan yang ada di buku saku. Bagi mereka yang dapat menjawab latihan, akan mendapatkan reward untuk dirinya dan mendapatkan point untuk kelompoknya yang tampil.

c) Presentasi hasil kerja kelompok

Kebanyakan mereka semangat dan antusias untuk tampil kedepan. Karena suasana belajarnya menyenangkan, sambil belajar bisa bermain.

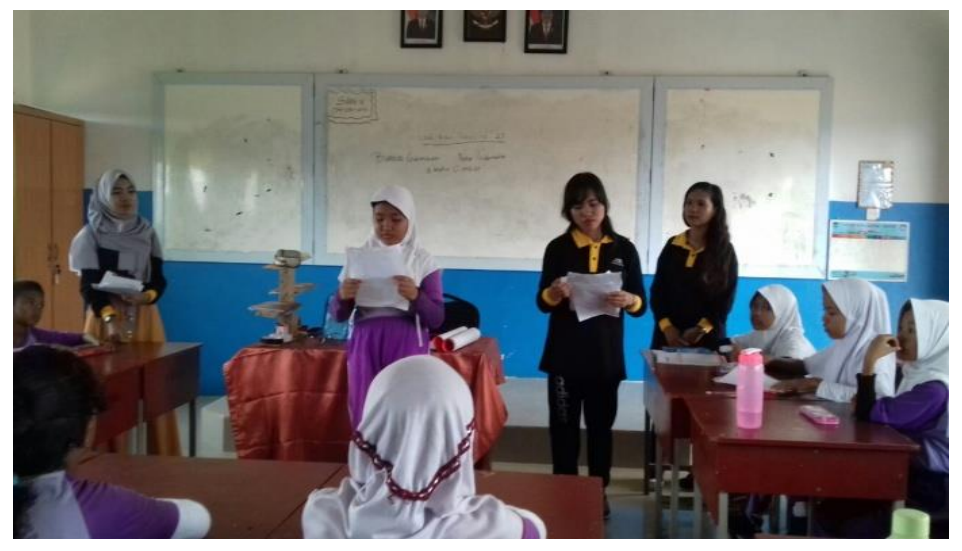

Figur 3. Foto Presentasi hasil kerja kelompok

Adapun hasilnya dapat juga di lihat dari latihan soal yang diberikan kepada peserta didiksetiap pertemuan. Dapat juga dilihat pada tabel dibawah ini:

Tabel.1. Data Nilai Latihan Siswa

\begin{tabular}{lcc}
\hline Nilai & Pertemuan I & Pertemuan II \\
\hline Nilai Maksimum & 100 & 100 \\
Nilai minimum & 63 & 68 \\
Rata-rata & 81,00 & 81,25 \\
KKM & 70 & 70 \\
\hline Jumlah Siswa & 25 & 25 \\
\hline
\end{tabular}


Berdasarkan tabel 1 di atas, bahwa nilai harian siswa dengan jumlah anaknya 25 anak memperoleh peningkatan hasil belajar yang dilihat dari nilai rata-rata kelasnya setiap pertemuannya. Hal ini menunjukkan bahwa rata-rata nilai yang diperoleh pada pertemuan I adalah 81, 00 dengan nilai maksimum 100, nilai minimum 63 dan pertemuan II, rata 81, 25 dengan nilai maksimum 100 dan minimum 68. Juga melebihi dari nilai KKM yang ditetapkan disekolah tersebut. Berarti dapat disimpulkan bahwa minat belajar siswa dengan menggunakan permainan monopoli berbantuan buku saku dapat meningkat hasil belajar yang dilihat dari latihan soal yang diberikan setiap pertemuannya. Jadi dapat disimpulkan bahwa minat belajar siswa berbantuan buku saku dengan permainan monopoli dapat meningkat hasil belajarnya. Hal ini sejalan dengan penelitian (Muhtarom, Nizaruddin, dan Sugiyanti, 2016) Jika dilihat dari segi permainan matematika, maka hasil penelitiannya menunjukkan bahwa pembelajaran berbasis permainan memiliki kelebihan dari pembelajaran "konvensional"(tanpa menggunakan permainan).

3.Tahap Penilaian

Proses penilaian dilaksanakan setiap pertemuannya sekitar 20 menit sebelum pembelajaran berakhir, dimana penilaian ini dilakukan dengan cara peserta didik di beri soal sebagai latihan untuk memahami materi (penguasaan materi) yang telah mereka pelajari tanpa membawa catatan dan penilaian juga dilakukan dengan tes lisan untuk masing-masing individu yaitu tutor memberikan beberapa soal langsung terkait dengan materi yang diajarkan. Contohnya menghitung bilangan bulat dengan cepat. Bagi peserta didik yang dapat lebih dahulu, maka mereka diberi reward (penghargaan) berupa buku atau pena satu buah.

Dari berbagai serangkaian pelaksanaan kegiatan yang dilakukan, setiap peserta bimbingan belajar sudah dinyatakan mampu memahami materi dengan baik dan bisa mengerjakan latihan dengan sendiri, baik dengan tulisan maupun dengan lisan tentang apa yang telah diajarkan. Namun ada juga beberapa peserta memiliki kemampuan yang berbeda, tetapi mereka punya semangat untuk belajar bersama dengan temannya disaat mereka diskusi. Adapun hasilnya juga, dapat dilihat dari peserta didik dapat menguasai materi dengan baik, dimana latihan yang dikerjakan dalam dua kali pertemuan memperoleh rata-rata $80 \%$ lebih. Melalui bimbingan belajar ini, mereka lebih menyukai belajar 
matematika, karena belajar sambil bermain dengan permainan monopoli (ular tangga) menyenangkan.

\section{KESIMPULAN}

Hasil-hasil yang dicapai selama pelaksanaan program pengabdian bimbingan belajar yaitu untuk program bimbingan belajar ini menemukan perubahan kemampuan dari peserta bimbingan belajar, dimana mereka yang awalnya belum mengetahui cara menghitung bilangan bulat dengan cepat apalagi angka bilangan bulatnya paling besar seperti $-120+30$, mereka belum bisa untuk menjawabnya. Kadang mereka malu dan takut-takut untuk menjawab, melalui bimbingan belajar ini peserta didik memiliki keberanian untuk bisa menjawabdan memiliki kemampuan dalam memahami materi yang telah diajarkan, walaupun ada beberapa peserta memiliki kemampuan yang berbeda, tetapi mereka punya semangat dan mereka terlihat antusias untuk belajar bersama dengan temannya disaat diskusi. Namun hasil ini sangat memuaskan bagi peserta didik. Melalui bimbingan belajar ini pula peserta didik yang awalnya takut dan tidak suka terhadap pelajaran matematika menjadi suka dengan matematika, bukan untuk ditakuti. Karena belajar sambil bermain dengan permainan monopoli (ular tangga) menyenangkan.

Hambatan-hambatan yang dihadapi selama pelaksanaan program pengabdian yaitu hambatan teknis dan hambatan nonteknis. Adapun hambatan teknis yang diperoleh adalah kemampuan peserta didik dalam berhitung sebagian ada yang kurang, tetapi mereka memiliki semangat dalam belajar. Sedangkan hambatan non teknis dalam program pengabdian ini, karena factor dana dan waktu yang kurang dalam program pengabdian ini.

\section{REFERENSI}

Artantri. 2005. Media Pembelajaran. Jakarta. Rajawali Press

BSNP. 2006. Standar isi untuk Satuan Pendidikan Dasar dan Menengah.Jakarta:BSNP.

Husna, A. 2017. Pelatihan Penggunaan Metode Jarimatika Untuk Menanamkan Konsep Cara Mudah Menghitung Perkalian Pada Siswa Sekolah Dasar. RW.01 Kelurahan Kibing. Jurnal Minda Baharu. Vol. 1(1):19-24. 
Ismawati, Esti.2012. Perencanaan Pengajaran Bahasa. Yogyakarta:Ombak

LPPM UNRIKA. 2018. Panduan Pengabdian Pada Masyarakat. Lembaga Penelitian dan Pengabdian pada Masyarakat (LPPM) Universitas Riau Kepulauan, tahun 2018.Batam. Universitas Riau Kepulauan.

Muhtarom, Nizaruddin, \& Sugiyanti. 2016. Pengembangan Permainan Teka-Teki SilangDalam Pembelajaran Matematika Di kelas VII SMP.. Jurnal Pythagoras. Vol. 5(1):20-31

Sardiman, S. Arief. 2011. Interaksi \& Motivasi Belajar Mengajar. Jakarta:Rajawali Press

Seto. 2010. Media Pembelajaran. Jakarta. Rajawali Press

Sartikaningrum, Ria.2013. Pengembangan Media Pembelajaran Monopoli Akuntansi Untuk Meningkatkan Motivasi Belajar Siswa Kelas X SMK Negeri 1 Tempel.Skripsi.Yogyakarta:Pendidikan Akuntansi UNY.

Suprapto, Anis Nuryati. 2013. Permainan Monopoli Sebagai Media Untuk Meningkatkan Minat Belajar Tata Boga Di SMA. JurnalImiah Guru. No.01/Tahun XVII/Mei 2013. 